\section{Celltech's deal with MRC}

The Medical Research Council revealed last week the broad outlines of its five-year agreement with Celltech, signed on 6 November last. The agreement raises perturbing prospects of delays in the disclosure of scientific information. It concerns work done by researchers directly employed by the council and not that of its grant-holders employed by universities.

The council has undertaken to inform Celltech of commercially interesting discoveries by its researchers in fields related to biotechnology before the work is published. (In other fields, the traditional relationship with the National Research Development Corporation will be maintained.) The council says that the freedom of its research workers to communicate with other academic scientists will not normally be impaired, but occasionally publication would have to be delayed "for a short period" while a decision is taken on patenting.

Dr Sydney Brenner, director of the Laboratory of Molecular Biology and a member of Celltech's Science Council, is unconcerned. Delays will not be serious, and the issues involved are less difficult than those which arise when individuals have links with commercial companies.

In return for the right to information (and ultimate exploitation), Celltech will give the council a "substantial proportion" of any royalties or profits that ensue. The council will place this money in a separate "Celltech fund". When the fund reaches a sensible level, a subcommittee will call for proposals from both universities and council establishments on how it should be spent. In the early stages, when the fund is limited, grants will be restricted to fundamental research in areas related to biotechnology. If the money rolls in, the scope of the fund will be widened.

If, however, the sum in the fund rises beyond a fixed limit, which has been agreed between the Department of Education and Science and the council, but which neither will reveal because of its quasi-commercial nature, the dispensation that allows the council to accept money from Celltech will have to be renegotiated. Hitherto, the arrangement between the research councils and the development corporation has been that the research councils can receive no such payment.

Robert Walgate

\section{Polish universities}

\section{Sit-in complete}

Last week, Poland's month-old student sit-in in Lodz ended with the signing of a wide-ranging agreement on academic autonomy. The students' action had begun over alleged delays by the Ministry of
Science, Higher Education and Technology in registering the new Independent Students' Association (NZS). Later, as the Lodz University students were joined by those from the Lodz Technical University and Medical School, and then by students in Poznan, Krakow and Warsaw, their package of "postulates" grew to more than fifty issues.

The problem of getting NZS registered had been dragging on since last November, when a limited sit-in at Warsaw University won a promise that the ministry would produce the necessary regulations by 20 December. Difficulties with the statutes of NZS were finally resolved last week, by the inclusion of a clause stating that NZS would abide by the constitution of the Polish People's Republic, but without specific mention of the "leading role" of the Party.

The major part of the Lodz Accord, however, sums up progress on the promised liberalization of Polish academic life. Several clauses therefore simply reiterate what has already been conceded. These include: the abolition of "reserved" places at universities, granted at the discretion of rectors or ministry officials to candidates whose performance in the entrance examinations did not merit their admission; university courses to be decided by the staff of the universities concerned; staff appointed on academic merits only; student participation in university government, and the election of university rectors by the academic senate in secret ballot.

Of the new demands raised at Lodz, the most radical have been dropped, including the reduction of military service and the abolition of compulsory courses on Marxism. (Some choice in "sociopolitical subjects" has, however, been conceded.) One major gain for the students concerned language courses. This had been strongly opposed by the minister, Dr Janusz Gorski, who had argued that a university is not geared to teaching foreign languages $a b$ initio. Nevertheless, there will now be a wider choice of languages to be studied as subsidiary subject, in effect ending the compulsory Russian which many science students in particular resented. Having had several years of Russian at school, they say they would like to study a Western language, to have greater access to current research literature.

Access to information should also be facilitated by clauses promising larger editions of textbooks (most students now have to make do with secondhand texts), more foreign currency for buying foreign journals and research apparatus and more open availability of existing literature.

A new system of student grants "more in tune with the principles of social justice" is promised for 15 May, when it will be submitted to the students for consultation. By May, too, the detested "practical training"' in manual labour will be replaced by paid voluntary physical work.
Student participation in university senates and faculty councils is set at 20-33 per cent, the student delegates to have full voting rights except in the awarding of academic degrees and titles.

The students also seem to have won their demand that the police should not be able to enter university premises at will. This clause, however, will presumably have to undergo some modification before the new legislation on higher education finally comes before the Sejm (Parliament), if campuses are not to provide an unintended sanctuary for, say, a purse-snatcher on the run. Inclusion of the clause, however, seems to reflect just how far the authorities are prepared to accept the concept of university autonomy.

What is clearly less acceptable, however, is the prospect of further unrest. Before finally approving the NZS statutes, therefore, Dr Gorski made sure that they contained some limitation on future militancy. The ministry's revisions laid down that strike procedures would follow the pattern of the "Solidarity" statutes, with the additional proviso that a sit-in can be proclaimed only by the majority decision of a specially convened meeting of a students' organization, in consultation with the authorities of the higher educational establishment(s) concerned.

Vera Rich

\section{US science budget \\ Reagan's way}

\section{Washington}

In the absence of any explicit science policy - and, indeed, of any official presidential science adviser - the new Reagan Administration has adopted a "back-to-basics" approach in deciding where the budget axe should fall on federally sponsored research programmes.

Last week, Mr Reagan submitted to Congress the cuts which he is proposing, as part of a "national program for economic recovery", in the budget recommendations made by $\mathrm{Mr}$ Carter last month.

As expected, the main cuts will fall on those additional areas of responsibility which the federal government has taken on in recent years but which Mr Reagan is suggesting should be returned to individuals, to states or to private corporations and other institutions.

In the universities, for example, he proposes to eliminate a new fund for modernizing research equipment which $\mathrm{Mr}$ Carter had proposed creating in the National Science Foundation, with an initial budget of $\$ 75$ million. Mr Reagan also wants to cut federal support for biomedical research institutions previously provided through the National Research Service Awards.

The Department of Commerce's National Oceanic and Atmospheric Administration (NOAA) would see its budget cut by more than two-thirds, 


\section{Threat to solar mission}

\section{Washington}

European scientists could suffer directly from Mr Reagan's proposed budget cuts through a recommendation that the United States reduce its commitment to the international solar polar mission, a two-spacecraft programme run jointly by the National Aeronautics and Space Administration (NASA) and the European Space Agency (ESA).

Although no details of the reduced commitment have been officially announced, the White House is said to have suggested that NASA should stop work on its own spacecraft. This would effectively eliminate half of the project, and seriously reduce its scientific value, much of which depends on the simultaneous collection of data from the two spacecraft as they follow polar orbits around the Sun.

NASA and ESA officials are now discussing the implications of $\mathrm{Mr}$ Reagan's proposal, which could still be modified before the details of the new budget are announced on $10 \mathrm{March}$. The solar polar mission was threatened with termination by Congress last summer, but survived after vigorous intervention by the State Department and the Office of Science and Technology Policy.

Under the budget proposal submitted to Congress by President Carter last month, the two spacecraft would be launched from the space shuttle, using a modified Centaur launcher as a substitute for the delayed inertial upper stage, early in 1986.

David Dickson

including an end to grants to states to protect their coastal zones, a 50 per cent reduction in support of college research under the Sea Grants programme, and the deferment of the National Ocean Satellite System (NOSS).

As for the private sector, a firm belief that the federal government should not interfere with the mechanics of the marketplace is reflected in substantial cuts to the Department of Energy's research and development budget. These would eliminate many of the department's efforts to demonstrate the commercial potential of new energy technologies, such as synthetic fuels, coal liquefaction and solar energy; but the aim is to maintain a basic commitment to long-range research projects considered too expensive or too risky by the private sector.

Public reaction to the proposed cuts from the scientific community has so far been muted. This is partly because precise details of where the cuts will fall will not be announced until 10 March and partly because there is little at present to be gained in Washington by speaking out against massive cuts in federal expenditure. Privately, however, laboratory chiefs and university presidents are already pulling all the strings they can, both within Washington's scientific establishment and among their congressional allies, to protect their own research programmes.

Some may already have been effective. A proposal from $\mathrm{Mr}$ David Stockman, director of the Office of Management and Budget, to eliminate the National Aeronautics and Space Administration's Galileo mission to Jupiter was removed from the President's message to Congress. Given a decision to defer the Venus Orbiting Imaging Radar, this would have virtually wiped out all future planetary research at NASA's Jet Propulsion Laboratory in California, Mr Reagan's home state.

On other proposals, there are bitter fights in prospect. Most of the projects that Mr Reagan is proposing to defer have been argued for by the scientific community strong and hard. These include NASA's gamma-ray observatory (already approved for funding by Congress), the National Science Foundation's 25-metre millimetrewave radioastronomy dish and the NOSS satellite system.

Funding for space transportation systems will be maintained at a level adequate to cover the costs of the space shuttle, at the expense of slower development for Spacelab, and the rescheduling of space science flights - Galileo, for example, is likely to be shifted back from a 1985 to a 1986 launch. There will also be no funds for the solar electric propulsion system for which, in the absence of a Halley's comet mission, no applications have been approved.

At the National Science Foundation, budget restrictions will, as previously rumoured, be concentrated on programmes that are "narrowly focused or of less immediate priority" - such as innovation in small businesses and international scientific efforts - as well as on new initiatives in science and engineering education, and on research in the behavioural, social and economic sciences.

In contrast, there would be no reduction in the previously proposed 17 per cent increases for research in the mathematical and physical sciences, or the 20 per cent increase for engineering research. Both are considered by the new Administration to be "of relatively high importance to future technological advancement and to the long-term health of the nation".

In energy research, $\mathrm{Mr}$ Reagan is proposing a reduction of $\$ 40$ million in the $\$ 607$ million which had been suggested for basic energy sciences. Details of how this cut will be distributed are still being discussed. Most of it is likely to fall on highenergy physics, which accounts for twothirds of the total, and will suffer the delayed construction of new facilities.

Biomedical research has been left relatively untouched ; where the previous Administration had suggested a relatively modest 9 per cent increase for the National Institutes of Health (NIH), Mr Reagan is suggesting a slight reduction in both 1981 and 1982 funding that will reduce this to 6 per cent. Much of the saving would come from reduced payment to educational institutions for NIH research training, which the Administration says would eliminate the practice of paying more to an institution for a federally supported trainee than would be charged for those who are not federally supported.

The Administration says that even though its proposed new budget for NIH would not fully cover the projected inflation rate - and that real reductions below the present base will therefore have to be made across all NIH institutes - it is committed to maintaining a substantial number of new research awards. It is therefore likely to continue the previous Administration's strategy of focusing on competitive project grants, rather than programme grants or intramural research.

David Dickson

\section{UK nuclear energy \\ CEGB sheepish}

The British nuclear industry is outwardly unruffled by criticisms from the House of Commons Select Committee on Energy last week (Nature 19 February, p.621). The general response is that the committee has misunderstood many of the issues. The strongest reaction is to the committee's criticism of the government's 1979 statement on nuclear power, which the committee took to be a commitment to build one nuclear station a year for the coming decade. This, it is said, was never the intention, so that the committee's recommendation that each reactor should be judged on its merits is already part of public policy.

The Central Electricity Generating Board (CEGB), the organization most sharply criticized, was the most sheepish last week. There is plainly some foundation for the charge that it had not been forthcoming with up-to-date estimates of cost and electricity demand. On the complaint that nuclear power stations are 34 per cent more expensive to build in Britain than elsewhere, Mr Glynn England, chairman of the board, is to meet nuclear suppliers and subcontractors to find ways of cutting costs and improving productivity on nuclear plant sites.

Mr England does not, however, accept the committee's view that the ordering of a second pressurized water station should be delayed for six or more years until the first, now being designed for the Sizewell site, is operating. Detailed studies and a public inquiry should provide enough information for the board to decide whether subsequent reactors should be based on pressurized water (as at Sizewell) or gas-cooled technology.

The Nuclear Installations Inspectorate also says that the committee has misunderstood its role. In particular, it 